\title{
THE IMPACT OF SPIRITUALITY ON MENTAL HEALTH PREGNANT WOMEN: A LITERATURE REVIEW
}

\author{
Habsyi Nur Hamidah ${ }^{1}$, Atika ${ }^{2}$ \\ ${ }^{1}$ Departement of Midwifery Education, Faculty of Medicine University Airlangga 60132, Surabaya, East Java, Indonesia \\ ${ }^{2}$ Departement Public Health, Faculty of Medicine University Airlangga 60132, Surabaya, East Java, Indonesia
}

Corresponding Author : atika.ikmkp@gmail.com

\begin{abstract}
The study aims to describe the impact of spirituality on the mental health of pregnant women. In this study uses a literature review method using a comprehensive strategy such as searching for articles in a research journal database. Article search uses Pubmed/MEDLINE and Springer Link in the time of frame (2016-2021). The keywords used in the search were Spirituality, Mental Health and Pregnant Women. There were 233 articles obtained, and 7 articles were analyzed through the purpose, suitability of the topic, sample size, research protocol, and the results of each article. The results of the study indicate that there is a significant effect of spirituality on the mental health of pregnant women, such as; reducing stress, decreasing fear of birth, increasing a sense of happiness and helping mothers control emotions and communicate them with people around them.
\end{abstract}

Keywords: Spirituality; Mental health; Pregnant women

\section{Introduction}

The most comprehensive approach adopted in providing health care is a holistic approach [1]. According to a holistic approach, an individual is a total physical, mental, emotional, socio-cultural and spiritual dimension and each of these dimensions is interrelated and interdependent with one another [2]. For health workers, paying attention to spirituality and religiosity, (in addition to one's emotional, physical and psychological dimensions) is important [3]. Spirituality is a broad concept with various dimensions and perspectives characterized by a feeling of attachment (connection) to something bigger than ourselves, which is accompanied by a search for meaning in life or can be described as an experience that is universal and touching [4].

Pregnancy is a very specific and complex period in a woman's life. The accompanying changes are not only observed in the biological/physiological field but also in its psychological and social functioning [5]. Some women may perceive pregnancy as a source of happiness, satisfaction, and self-satisfaction. However, other women may experience changes in their mental health, such as the development of anxiety during pregnancy [6]. Intense anxiety during pregnancy can be a risk factor for high mental health problems in maternal, such as postnatal depression, impaired mother-infant bonding, and obstetric complications, such as postmature or premature delivery and impaired fetal growth [7]. Religious coping behaviours, such as praying, are usually done to manage troublesome and stressful situations [8]. Many research studies have confirmed the effectiveness of religious coping behaviours in helping a person manage their feelings of depression and anxiety, as it enables them to overcome guilt, view suffering in a positive light, and control their fears [9]. Improving 
spirituality is recommended as a stress management and treatment strategy, because humans are all biological, psychological, social and spiritual aspects at the same time and stressing their spiritual needs is important, because it is a healthy lifestyle [10]

\section{Methods}

At the beginning of the search for data through titles and abstracts, 530 articles were obtained. With details; Pubmed/MEDLINE database obtained 11 articles, Springer Link database totalled 519 articles. Then the research was screened by title, abstract, full-text review, and year of publication. Furthermore, the remaining articles were excluded as many as 233 articles, the remaining 7 articles were analyzed in full. Thus, the final result of the literature selection was obtained by 7 articles. This is done so that all the articles obtained are relevant and in accordance with the topics raised. Furthermore, the articles obtained in full text are downloaded and stored and then analyzed again to find out the contents of each article.

\section{Result}

The main focus of this literature is pregnant women. To maximize the process of compiling this literature review, the researcher explains his findings through table 1.

Table 1 Review Of Research Result

\begin{tabular}{|c|c|c|c|c|}
\hline Author & $\begin{array}{c}\text { Sample } \\
\text { Characteristics }\end{array}$ & Study Design & Protokol & Result \\
\hline $\begin{array}{l}\text { (Abdollahpour \& } \\
\text { Khosravi, 2018) } \\
{[11]}\end{array}$ & $\begin{array}{l}245 \text { Pregnant } \\
\text { women in Iran }\end{array}$ & Cross-sectional & $\begin{array}{l}\text { Spiritual } \\
\text { intelligence, fear, } \\
\text { happiness }\end{array}$ & $\begin{array}{l}\text { Decreased fear of } \\
\text { childbirth and } \\
\text { increased feelings } \\
\text { of happiness in } \\
\text { pregnant women } \\
\text { are the effects of } \\
\text { high spiritual } \\
\text { intelligence. }\end{array}$ \\
\hline
\end{tabular}




\begin{tabular}{|c|c|c|c|c|}
\hline $\begin{array}{l}\text { (Piccinini et al., } \\
\text { 2021) [12] }\end{array}$ & $\begin{array}{l}160 \text { Brazilian } \\
\text { women in early } \\
\text { pregnancy. }\end{array}$ & Cross-sectional & $\begin{array}{l}\text { Spirituality, mental } \\
\text { health, quality of } \\
\text { life }\end{array}$ & $\begin{array}{l}\text { Low levels of } \\
\text { spirituality were } \\
\text { associated with } \\
\text { high levels of } \\
\text { stress, symptoms } \\
\text { of depression and } \\
\text { anxiety. Negative } \\
\text { coping is } \\
\text { associated with } \\
\text { poorer mental } \\
\text { health and quality } \\
\text { of life in pregnant } \\
\text { women. }\end{array}$ \\
\hline $\begin{array}{l}\text { (Durmus et al., } \\
\text { 2021) [13] }\end{array}$ & $\begin{array}{l}336 \text { Pregnant } \\
\text { women in Turkey }\end{array}$ & Cross-sectional & $\begin{array}{l}\text { Spiritual well- } \\
\text { being, depression, } \\
\text { fear }\end{array}$ & $\begin{array}{l}\text { Spirituality plays } \\
\text { an effective role in } \\
\text { reducing anxiety } \\
\text { and depression. } \\
\text { Spirituality is } \\
\text { important in } \\
\text { improving mental } \\
\text { health and to } \\
\text { reduce fear and } \\
\text { depression } \\
\text { pregnant women } \\
\text { need effective } \\
\text { spiritual care }\end{array}$ \\
\hline $\begin{array}{lcc}\text { (Bilgiç \& } & \text { Çıtak } \\
\text { Bilgin, 2021) } & \text { [14] }\end{array}$ & $\begin{array}{l}338 \text { Pregnant } \\
\text { women in Turkey }\end{array}$ & $\begin{array}{l}\text { Descriptive and } \\
\text { Relational Study }\end{array}$ & $\begin{array}{l}\text { Spirituality, fear of } \\
\text { childbirth, } \\
\text { psychological } \\
\text { well-being. }\end{array}$ & $\begin{array}{l}\text { Pregnant women } \\
\text { with positive } \\
\text { spiritual well- } \\
\text { being and } \\
\text { psychological } \\
\text { well-being } \\
\text { experience good } \\
\text { mental health } \\
\text { conditions, one of } \\
\text { which is lower fear } \\
\text { of childbirth }\end{array}$ \\
\hline
\end{tabular}




\begin{tabular}{|c|c|c|c|c|}
\hline $\begin{array}{l}\text { (Nodoushan et al., } \\
2020)[15]\end{array}$ & $\begin{array}{l}620 \text { Pregnant } \\
\text { women in Iran }\end{array}$ & Descriptive & $\begin{array}{l}\text { Spiritual health, } \\
\text { Stress }\end{array}$ & $\begin{array}{l}\text { Increasing stress } \\
\text { and decreasing the } \\
\text { mental health of } \\
\text { pregnant women } \\
\text { during COVID-19 } \\
\text { pandemic can } \\
\text { increase the } \\
\text { influencing factors } \\
\text { in preterm delivery } \\
\text { and unhealthy } \\
\text { birth }\end{array}$ \\
\hline $\begin{array}{l}\text { (Dolatian et al., } \\
\text { 2017) [16] }\end{array}$ & $\begin{array}{l}450 \text { Pregnant } \\
\text { women in Iran }\end{array}$ & $\begin{array}{l}\text { Descriptive } \\
\text { correlational study }\end{array}$ & $\begin{array}{l}\text { Spirituality, } \\
\text { psychological } \\
\text { well-being, } \\
\text { pregnancy-specific } \\
\text { stress }\end{array}$ & $\begin{array}{l}\text { Spirituality } \\
\text { reducing } \\
\text { pregnancy-specific } \\
\text { stress. Higher } \\
\text { spirituality helps } \\
\text { individuals } \\
\text { experience positive } \\
\text { emotions through } \\
\text { effective } \\
\text { communication } \\
\text { with others }\end{array}$ \\
\hline $\begin{array}{l}\text { (Chehrazi et al., } \\
\text { 2021) [17] }\end{array}$ & $\begin{array}{l}200 \text { Pregnant } \\
\text { women in Iran }\end{array}$ & Cross-sectional & $\begin{array}{l}\text { Spiritual well- } \\
\text { being, anxiety, } \\
\text { pregnancy- } \\
\text { specific stress }\end{array}$ & $\begin{array}{l}\text { Spirituality was } \\
\text { negatively related } \\
\text { with bad mental } \\
\text { health condition, } \\
\text { such as; pregnancy } \\
\text { stress and state } \\
\text { anxiety }\end{array}$ \\
\hline
\end{tabular}

\section{Discussion}

Pregnancy is always associated with changes in the psychological function. It is usually associated with ambivalence, frequent mood swings, varying anxiety, fatigue, drowsiness, depressive reactions to excitement. Psychological adaptation to pregnancy involves reacting to the somatic changes of pregnancy, changing body image, adjusting to new social roles, forming a sense of self as a mother, and fostering a relationship with the fetus and then the newborn. Understanding the various normative perinatal changes can help in differentiating normal experiences from pathological experiences [18]. In community-based health, definitions of physical, mental and spirituality are considered as interdependent components of an individual's existence; maintaining one's health thus depends on maintaining a balance between all these aspects [19].

Mental health is an important aspect in realizing overall health. Although, in most developing 
countries, mental health problems have not been prioritized when compared to infectious diseases [20]. Various poor mental health conditions, such as; maternal anxiety, infant health, pregnancy-related illnesses, social problems, insomnia, and low social and family support can affect the mental health of pregnant women [21].

Research conducted by (Piccinini et al., 2021) stated that levels of spirituality have an effect on the mental health of pregnant women. In this study, data obtained that low levels of spirituality were associated with high levels of stress, symptoms of depression and anxiety. Negative coping is associated with poorer mental health and quality of life in pregnant women [12]. Several studies have shown that spirituality has an influence on an individual's mental health condition. Spirituality and religiosity can provide strength for individuals who experience negative emotions and suicidal ideation, as well as increase resilience when facing life's pressures [22]. High spirituality also has a significant effect on good social support, high self-esteem and can reduce psychosocial problems in high-risk pregnant women [23].

In this literature, research conducted by (Durmus et al., 2021) reported that 336 pregnant women living in a city in the Eastern Anatolia region of Turkey who was included in the study, found that spirituality plays an effective role in reducing anxiety and depression. Spirituality is important in improving mental health and to reduce fear and depression pregnant women need effective spiritual care. In addition, in a study conducted by (Bilgiç \& Çıtak Bilgin, 2021) reported that pregnant women with positive spiritual well-being and psychological well-being experience lower fear of childbirth. Efforts to be closer to God enable mothers to accept and adapt to the changes experienced during pregnancy. Spirituality is actually not only formed on beliefs in pregnant women, but is also influenced by various factors, such as family development, ethnic and cultural background $[24]$.

Research conducted by (Dolation et al., 2017) on 450 Iranian pregnant women found that spirituality can reduce stress and help individuals who are experiencing emotions to communicate effectively with others and thus they can evaluate events in his life better. In addition, a study conducted by (Chehrazi et al., 2021) on 200 Pregnant women in Iran also found that spirituality was negatively related with bad mental health condition, such as; pregnancy stress and state anxiety.

\section{Conclusion}

The results of this study try to describe how spirituality affects the mental health of pregnant women. The results of the study indicate that there is a significant effect of spirituality on the mental health condition of pregnant women, such as; reducing stress, decreasing fear of birth, increasing a sense of happiness and helping mothers control emotions and communicate them with people around them.

\section{Acknowledgments}

The author would like to thank all those who helped in writing this literature.

\section{References}

[1] K. M. Akgun and U. Celikkalp, "Nurses and Midwives Opinions about Spirituality and Spiritual Care,” Int. J. Caring Sci., vol. 9, no. 3, pp. 975-984, 2016, [Online]. Available: https://search.proquest.com/scholarly-journals/nurses-midwives-opinionsabout-spirituality/docview/1860631856/se-2?accountid=25704.

[2] A. L. Biro, "Creating conditions for good nursing by attending to the spiritual," J. Nurs. Manag., vol. 20, no. 8, p. no-no, Jul. 2012, doi: 10.1111/j.1365-2834.2012.01444.x. 
[3] C. Oboyle, V. Brady, and F. Timmins, "Making space for spirituality in childbirth,” J. Clin. Nurs., vol. 26, no. 19-20, pp. 2823-2825, 2017, doi: 10.1111/jocn.13795.

[4] I. Ardian, "Konsep Spiritualitas dan Religiusitas dalam Pasien DM Tipe 2," NURSCOPE J. Keperawatan dan Pemikir. Ilm., vol. 5, pp. 1-9, 2016.

[5] A. Bjelica, N. Cetkovic, A. Trninic-Pjevic, and L. Mladenovic-Segedi, "The phenomenon of pregnancy - A psychological view," Ginekol. Pol., vol. 89, no. 2, pp. 102-106, 2018, doi: 10.5603/GP.a2018.0017.

[6] F. Yuksel, S. Akin, and Z. Durna, "Prenatal distress in Turkish pregnant women and factors associated with maternal prenatal distress,” J. Clin. Nurs., vol. 23, no. 1-2, pp. 54-64, Jan. 2014, doi: 10.1111/j.1365-2702.2012.04283.x.

[7] I. Mappa, F. A. Distefano, and G. Rizzo, "Effects of coronavirus 19 pandemic on maternal anxiety during pregnancy: a prospectic observational study,” J. Perinat. Med., vol. 48, no. 6, pp. 545-550, Jul. 2020, doi: 10.1515/JPM-2020-0182.

[8] J. Jong, "Death anxiety and religious belief: a critical review," in The Science of Religion, Spirituality, and Existentialism, Elsevier, 2020, pp. 21-35.

[9] A. Vishkin and M. Tamir, "Fear not: religion and emotion regulation in coping with existential concerns," in The Science of Religion, Spirituality, and Existentialism, Elsevier, 2020, pp. 325-338.

[10] Vikas K. Rohit and Suresh M. Makwana, "Lifestyle: A Comparative Study of the Arts and Science college students," Int. J. Indian Psychol., vol. 2, no. 2, Mar. 2015, doi: 10.25215/0202.065.

[11] S. Abdollahpour and A. Khosravi, "Relationship between Spiritual Intelligence with Happiness and Fear of Childbirth in Iranian Pregnant Women,” Iran. J. Nurs. Midwifery Res., vol. 23, no. 1, pp. 45-50, 2018, doi: 10.4103/IJNMR.IJNMR_39_16.

[12] C. R. P. Piccinini, V. de Castro Almeida, O. da Silva Ezequiel, E. F. de Matos Fajardo, A. L. G. Lucchetti, and G. Lucchetti, "Religiosity/Spirituality and Mental Health and Quality of Life of Early Pregnant Women," J. Relig. Health, vol. 60, no. 3, pp. 1908-1923, Jun. 2021, doi: 10.1007/S10943-020-01124-2.

[13] M. Durmuş, Z. Öztürk, N. Şener, and S. Y. Eren, “The Relationship between the Fear of Covid-19, Depression, and Spiritual Well-Being in Pregnant Women,” J. Relig. Health, no. 0123456789, 2021, doi: 10.1007/s10943-021-01448-7.

[14] G. Bilgiç and N. Çıtak Bilgin, "Relationship Between Fear of Childbirth and Psychological and Spiritual Well-Being in Pregnant Women,” J. Relig. Health, vol. 60, no. 1, pp. 295-310, 2021, doi: 10.1007/s10943-020-01087-4.

[15] R. J. Nodoushan, H. Alimoradi, and M. Nazari, "Spiritual Health and Stress in Pregnant Women During the Covid-19 Pandemic,” SN Compr. Clin. Med., vol. 2, no. 12, pp. 2528-2534, 2020, doi: 10.1007/s42399-020-00582-9.

[16] M. Dolatian, Z. Mahmoodi, T. Dilgony, J. Shams, and F. Zaeri, "The Structural Model of Spirituality and Psychological WellBeing for Pregnancy-Specific Stress,” J. Relig. Health, vol. 56, no. 6, pp. 2267-2275, 2017, doi: 10.1007/s10943-017-0395-z.

[17] M. Chehrazi, M. Faramarzi, S. Abdollahi, M. Esfandiari, and S. Shafie rizi, "Health promotion behaviours of pregnant women and spiritual well-being: Mediatory role of pregnancy stress, anxiety and coping ways,” Nurs. Open, vol. 8, no. 6, pp. 35583565, 2021, doi: 10.1002/nop2.905.

[18] L. J. Miller, Psychological, behavioral, and cognitive changes during pregnancy and the postpartum period., no. September 2018. 2016.

[19] B. Kozier, Fundamentals of Nursing: Concepts, Process and Practice. Pearson Education, 2008.

[20] I. A. Ridlo, "Jurnal Psikologi dan Kesehatan Mental Pandemi COVID-19 dan Tantangan Kebijakan Kesehatan Mental di Indonesia,” Dep. Adm. dan Kebijak. Kesehatan, Fak. Kesehat. Masy. Univ. Airlangga, pp. 155-164, 2020, doi: 10.20473/jpkm.v5i12020.155-164.

[21] G. Pawar, C. Wetzker, and D. Gjerdingen, "Prevalence of depressive symptoms in the immediate postpartum period," J. Am. Board Fam. Med., vol. 24, no. 3, pp. 258-261, May 2011, doi: 10.3122/JABFM.2011.03.100249.

[22] B. Hodapp and C. Zwingmann, "Religiosity/Spirituality and Mental Health: A Meta-analysis of Studies from the GermanSpeaking Area," J. Relig. Health, vol. 58, no. 6, pp. 1970-1998, Dec. 2019, doi: 10.1007/S10943-019-00759-0.

[23] D. E. Jesse and P. G. Reed, "Effects of Spirituality and Psychosocial Well-Being on Health Risk Behaviors in Appalachian Pregnant Women,” J. Obstet. Gynecol. Neonatal Nurs., vol. 33, no. 6, pp. 739-747, Nov. 2004, doi: $10.1177 / 0884217504270669$.

[24] Ruslinawati, “KorelasiKebutuhan Spiritual Pada Ibu Hamil Dengan Tingkat Kecemasan Intrapartum,” Caring Nurs. J., vol. 1, 
no. 1, pp. 1-5, 2017, [Online]. Available:

https://www.academia.edu/35139190/KORELASI_KEBUTUHAN_SPIRITUAL_PADA_IBU_HAMIL_DENGAN_TINGKA

T_KECEMASAN_INTRAPARTUM_Correlation_of_Spiritual_Needs_In_Pregnant_Woman_With_Intrapartum_Anxiety_Rate 